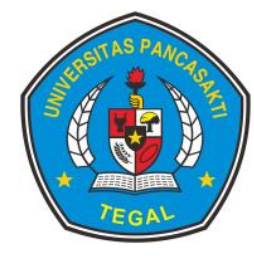

JURNAL ILMU PEMERINTAHAN:

Kajian Ilmu Pemerintahan dan Politik Daerah

Volume 6- Nomor 1, April 2021, (HIm 1-12)

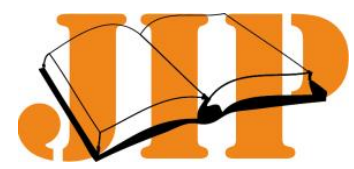

Available online at: http://governmentjournal.org/

\title{
Susilo Bambang Yudhoyono's Government Policy in Handling The Aceh Tsunami: a Historical Research
}

\author{
Agus Danugroho ${ }^{*}$ \\ a Universitas Gadjah Mada, Indonesia
}

\begin{tabular}{l}
\hline Information Article \\
\hline History Article \\
Submission : 6-11-2020 \\
Revision : $17-02-2021$ \\
Accepted : $23-02-2021$
\end{tabular}

DOI Article:

10.24905/jip.6.1.2021.1-12

\begin{abstract}
A B S TRACT
Tsunami Aceh 2004 was one of the disasters whose status was designated as a national disaster in Indonesia. The event occurred compilation Indonesia does not yet have a special body and legislation governing natural disaster management. The Aceh tsunami has significant significance for the Indonesian community to the international level. The Aceh tsunami caused many complicated problems that had to be resolved by the Susilo Bambang Yudhoyono Government, among others, the regional government was unable to function properly, the disaster management law did not exist, supported international assistance in the military, and the National Budget was not available for the Aceh emergency response. The research objective in this study is about research conducted by the government of Susilo Bambang Yudhoyono in the 2004 tsunami in Aceh. The research method uses historical, heuristic, critical, interpretation, and historiographic methods. The results of this study are that the Government of Susilo Bambang Yudhoyono can resolve the problem by triggering regulations regarding the Law and the Special Body to handle problems that did not exist before.
\end{abstract}

Keyword: History of Disasters; Aceh Tsunami 2004; Susilo Bambang Yudhoyono

(C) 2021 Published by Governmental Studies. Selection and/or peer-review under responsibility of JIP.

* Corresponding author.

E-mail address: a.danu1997@gmail.com 


\section{Jurnal Ilmu Pemerintahan: Kajian Ilmu Pemerintahan dan Politik Daerah,}

Vol. 6 (1), April 2021 - 2

\section{Agus Danugroho}

\section{Introduction}

The government Susilo Bambang Yudhoyono (hereinafter will be written SBY) set the main priority in his leadership, namely the eradication of collusion, corruption, and nepotism or commonly called KKN (Sri Cahyadi Nugroho, 2017). In addition to the main priority of such programs launched by the during the period of the government of SBY among other things, the reduction climate change and the environment, preparedness to cope with disasters, as well as improve production and food security. Of any the program of the government of SBY that can be directly billed by the nation Indonesia is a program of preparedness natural disaster response.

Some months of the completion of the sworn in as President of Indonesia in the month December natural disaster of Tsunami that happened in Aceh. According to data from the BPS recorded approximately 130.013 people died \& 37.066 a missing person. This disaster destroyed the settlements as a result the population of homeless \& displaced. Approximately 500,000 refugees, most of adultchild, women, \& old people. In addition to physical influences, of this disaster put psychological influence that resulted in stress weight prolonged.

Tsunami Aceh resulted in complicated problems which must be solved the the government of SBY. The problem, among others, local Government that is not running properly, as well as regulations legislation and agencies that deal with natural disasters such as The Tsunami in Aceh that require a lot funds to countermeasures (Danugroho et al., 2020).

The government SBY apply some stages of the restoration of the Province of Nanggroe Aceh Darussalam affected by natural disasters the Tsunami. Three stages of recovery it is produced from the meeting of the session of the cabinet plenary. The government of SBY made the initial stage to handle Tsunami Aceh 2004. Step by step is made systematically and according to some of the considerations. The preparation of the steps and stages of it referring to the results of study of the National Coordination Body or BAKORNAS in disaster management and the handling of refugees.

The government SBY in the settlement of the existing problems and to cope with natural disasters Tsunami Aceh take policy measures such as, declare a Disaster in Aceh as a national disaster that stated in Presidential Decree Number 112 year 2004, with the aim of restoring the function of Local Government is not running because Tsunami-hit Aceh. But how its implementation? it is appropriate with the guidelines or implementation instructions so that could affect the success of the response operations emergency Tsunami natural disaster in Aceh.

Based on the above description, it is very interesting to examine the handling of the Tsunami Aceh 2004 by the Government of SBY. Aceh Tsunami is the deadliest natural disasters that occurred in the reign of SBY. Conditions Aceh time of occurrence of the Tsunami is still filled with the atmosphere of the unresolved conflict. In addition, the post-Tsunami Aceh, many new problems arise that must be resolved in the handling of the Tsunami disaster in Aceh. In addition, in search of novelty of the research in this study, the researchers used the software VOSViewer.

Although many software program to analyze the units of the text and the similarity matrix will be but an excess of VOSviewer is on the aspects of the visualization (van Eck \& Waltman, 2010). The results of processing the VOSViewer by the researchers showed that the trend of research in the 2004 Aceh Tsunami associated with the development of the region and Natural Disaster are common. Research that is rarely done according to the analysis of VOSViewer with regard to the political aspect in the event of a natural disaster. With the results of VOSViewer can prove that the research is about the politics and history of natural disasters is still 


\section{Jurnal Ilmu Pemerintahan: Kajian Ilmu Pemerintahan dan Politik Daerah, Vol. 6 (1), April 2021 - 3 \\ Agung Danugroho}

rarely examined and it is an opportunity for researchers to develop research related about politics in the handling of natural disaster.

This study is considered important because of the Tsunami in Aceh has a significant impact for human life. The Tsunami in Aceh as already described above, set by the President to be a National Disaster. Natural disasters set to be a National Disaster definitely need serious treatment of the central Government. In this case the role of the government of SBY is very important for victims of natural disasters. Handling of the 2004 Aceh Tsunami can be a substantiation of the initial steps the government of SBY in dealing with the crisis. How big is the government of SBY able to resolve the problems that arise due to the Tsunami in Aceh in 2004.

\section{Method}

Methods the research used in this writing using the method history because according to the scientific field researchers (Gottschalk, 1985). Based on the research method used is the method of history research then need to be implemented some of the steps or the procedure in his research among other Heuristics, Criticism, Interpretation, and Historiography.

\section{Results and Discussion}

The 2004 Tsunami in Aceh have a broad impact for the government and the international world (Danugroho et al., 2020). To rebuild the region of Aceh, the Government of SBY attempt to deal with the disaster. The implementation of these efforts the Government is assisted by various donor agencies abroad in every process of mitigation. Researchers using the reference theory of public policy from William Dunn to see the stages of the handling is done by the Government of SBY. Public policy is the pattern of the dependence of the complex of collective choices are interdependent, including decisions not to act, which is made by the agency or the office of the government (Dunn, 2003).

In summary, the scope of public policy studies is very broad as it covers various fields and sectors such as economic, political, social, cultural, legal, and so on. It is seen from the hierarchy of his public policy can be national, regional or local legislation, government regulation, presidential decree, regulation, government regulation regions or provinces, the decision of the governor, the regulations of the district or city, and the decision of the mayor or regent. Process of public policy making is a complex process because it involves a lot of processes and variables that should be studied. Therefore some political experts who took an interest to examine the public policy divide the process-the process of drafting public policy into several stages.

The purpose of such division is to facilitate the study of public policy. Stages of public policy according to William Dunn, among others, policy making, policy formulation, policy adoption, policy implementation and policy evaluation. In the handling of the Tsunami in Aceh if seen from its history can be divided into 3 stages of the measures taken, namely (1) emergency response, (2) rehabilitation efforts, and (3) the efforts of reconstruction.

\section{The Phase of The Emergency Response}

Phase natural disaster management Tsunami Aceh is the first Phase Emergency Response. Phase of Emergency Response was implemented 3 months after the the occurrence of the tsunami i.e., in January to March 2005. Its main purpose is saved the victims and their needs to survive. The phase of the Emergency Response implemented after the determination of the status of natural disaster the Tsunami of Aceh to be a disaster national by the Government of SBY. After the determination of the status of the disaster national marked with the release of Presidential Decree Number 112 2004, the SBY Government issued a policy to doing this phase which was conducted over 3 months and over on March 26, 2005, the policy in question is the expenditure of the presidential Instruction No. 1 Year 2005. 


\section{Jurnal Ilmu Pemerintahan: Kajian Ilmu Pemerintahan dan Politik Daerah, Vol. 6 (1), April 2021 - 4}

\section{Agus Danugroho}

The implementation of the Phase of Emergency Response according to the estimated needs a budget of as much as Rp. 2 Trillion. The budget used for the implementation of the completion of the shelter or Shelters and the division of logistics to all the victims of natural disasters tsunami in Banda Aceh, Aceh Besar, Aceh Jaya, Aceh Barat, Lhokseumawe, Langsa, Aceh South, Singkil, Pidie, and Bireun. With the determination of the status national disaster opens up opportunities for international assistance from the many countries, among others, the United States, Australia, Switzerland, Russia, Qatar to provide assistance. Indonesia gets sympathy and attention of the world so that countries and international organizations such as UNDP, IFRC, UN, UNESCO, and Other Donor institutions. A wide range of help is given as, aid, food aid, sanitation, shelter, air transport, medical assistance. (Sisira \& McCawley, 2010)

Help United States (US) to the emergency response Tsunami Ocean Indian officially published in the bulletin released by the US Agency for International Development, Bureau for Legislative and Public Affairs (2004). Indonesia to get help from the United States as much as $\$ 100,000$ channelled through the red cross and disaster management agency .

Help of the United States is diverse and is dominated by the help of non-food products such as military personnel, medical assistance, utilities sanitation, household use, tents, and hygiene team. Military U.S. sent a team of air US Abraham Lincoln to distribute food and clean water to the refugees on the coast of Aceh. Then, the helicopter and the plane U.S. navy from the aircraft carrier Abraham Lincoln and Bonhomme Richard flying assistance in the form of 4.8 million pounds of food, water and medicine. The American military evacuating the 3,000 victims of the tsunami in Indonesia to the shelters and hospitals. At the airport in Banda Aceh every in the morning, 20 officers of the U.S., German, Germany, Australia and other military meet with the officers to coordinate assistance (U.S. Agency for International Development, 2005) .
Australia the day after the tsunami in Aceh, precisely on December 27, 2004 send 4 helicopter types Hercules RAAF-C130 to send medical staff and the supply of humanitarian aid to Indonesia. The Total assistance from the Australian government for the handling of the emergency response to the Tsunami in Aceh amounted to \$34.4 million (Australian Government Department of Foreign Affairs and Trade, 2014).

In addition to Australia, the country of Switzerland also respon to the events of the Tsunami in Aceh quickly. Swiss Humanitarian Aid sending a Rapid Response Team to see the location and estimate the required needs. Switzerland accounted for amounted to CHF 11.3 million for the needs of emergency response in Indonesia. Switzerland also contributed financially to some of the organizers of the emergency activities such as IFRC, ICRC, WFP and OCHA (Swiss Agency for Development and Cooperation, 2009).

On the stage of the emergency response community, the Aceh provincial administration and the district or city in Aceh, the elements of the TNI, the Indonesian Red Cross, and a large number of national NGOS with the support of funding from national companies, public and government other areas, ready to help save the life of the impact of the tsunami. Thanks to the emergency response quick and structure cohesive societies, the victims of which more can be prevented. The response of the people of Indonesia are very enthusiastic in helping the people of Aceh. Support the emergency response of local NGOS to accelerate evacuation and burial of the victim, the handling of refugees, the granting of emergency assistance, city cleaning and preparation of temporary occupancy.

Attention the international community, the magnitude of the willingness (commitment) donors multilateral and bilateral. Recorded about 700 million the U.S. dollar has been promised by various donors to the government Indonesia. On January 6, 2005 at the initiative of the PRIME 


\section{Jurnal Ilmu Pemerintahan: Kajian Ilmu Pemerintahan dan Politik Daerah, Vol. 6 (1), April 2021 - 5 \\ Agung Danugroho}

minister of Singapore Lee Hsien Long, held an international meeting in Jakarta ASEAN Leader's Meeting on Aftermath of Tsunami Disaster. The meeting was attended by the UN Secretarygeneral Kofi Annan, US Secretary of state, PM Australia's John Howard, PRIME minister of Malaysia H. M. Abdullah Badawi, the President of the Laos, Thailand, Sri Lanka and India. The meeting was also attended by good representatives of donor agencies, multilateral (WB, ADB, UN, etc.) or from the agency bilateral donors (U.S., Japan, and the Netherlands) (BRR, 2005).

On stage emergency response has been successfully saved area of $80 \quad \mathrm{~m} 3$ documents/archives of the land belonging to the BPN Province NAD. Rescue efforts carried out in cooperation between the National Archives of INDONESIA, BPN, JICA, Tokyo Reservation and Conservation Center, Japan International Cooperation Systems. The Emergency relief phase ended with the release of presidential Instruction No. 1 2005. The deadline instructed by the president to complete the emergency response activities is until the end of March 2005. In the decision also urged to immediately implement the rehabilitation and reconstruction phase. President SBY through the instructions this formulate coordination across sectors that became the basis of the implementation of rehabilitation and reconstruction. The Instruction of The President issued in Jakarta on 2 March 2005.

\section{Rehabilitation Efforts}

Rehabilitation implemented the Government of SBY after completing Phase Response Emergency. Rehabilitation aims to restore and restore function buildings and infrastructure that need to be done to follow up the stage of emergency response, such as the rehabilitation of mosques, hospital, the social infrastructure base, as well as infrastructure and facilities the economy. The main goal of the rehabilitation is to improve public services up to an adequate level. In the stage of rehabilitation, also pursued the completion of various issues related to the legal aspect through settlement of rights to land, the rescue of documents of land, and handling the trauma of disaster victims (Danugroho et al., 2020). The target stage the rehabilitation of the most important and includes the rehabilitation of the main is the restoration of function of public services and the handling of trauma victims. Recovery of function of public services and the handling of trauma the disaster will be described below.

\section{Recovery of Function of Public Services}

Recovery the function of public service is necessary in order to restore and the success of the process of reconstruction that will be implemented. Space the scope of the implementation of the rehabilitation of the public service functions performed through activities such as the restoration of the environment of the region disasters, improvement of infrastructure and public facilities, the provision of assistance home improvement while the community, health services, reconciliation and conflict resolution, economic and cultural recovery security and order, as well as the restoration of the functions of government.

Recovery the environment of the region of Aceh in the year 2004 carried out after the stage the emergency response ended, i.e. at the end of 2005. Coverage in the restoration of the physical environment includes several activities such as environmental improvement of residential area, industrial area, district business, and the area of the building. Recovery improvement of residential areas done gradually. Its components, among others, the air environment, the aquatic environment, environmental, vegetation or commonly called with the plant, and also on the social environment. In the implementation the restoration of the first creation of a comfortable air environment.

Institutions donors abroad and within the country many of which provide assistance for the implementation of the recovery environment. Institutions that help in the rehabilitation 


\section{Jurnal Ilmu Pemerintahan: Kajian Ilmu Pemerintahan dan Politik Daerah, Vol. 6 (1), April 2021 - 6}

\section{Agus Danugroho}

process one of them is MDF (Multi Donor Fund). MDF play a strategic role in improving the effectiveness and efficiency of the process of recovery. The MDF provided technical assistance and help operational to the BRR in its role as program coordinator rehabilitation valued at approximately 7 million US dollars to complete its mandate in a timely and open(MDF, 2011). This includes help drafting policies, laws, project and program tool and process monitoring systems recovery since July 2005 to proceed with the program reconstruction.

Recovery initial MDF is to provide a delivery service allowing the many agencies involved in the recovery transport logistics in the form of food, clothing, and medicine to the west coast of Aceh and the landing place of the remote Island of Simeulue. After the early recovery phase, the fund MDF allocated on the effort restoration of infrastructure and transport. Through the project of MDF network infrastructure regional transport important can restored for a while waiting for the process of reconstruction goes. The road is Roads LamnoCalang which is the way the main hub on the west coast (MDF, 2011). Rehabilitation of the road is very important because it is used to distribute aid the logistics of the regional office to each region in the area of Aceh Jaya.

MDF in addition to helping the process of rehabilitation in the field of transport, MDF also help perform the recovery of the territorial community of Aceh. Recovery the community is done through some of the work program of the MDF own. The project is the PPK or Program Development The district and the District. KDP was implemented in 17 districts and 1 city in the Province of Nanggroe Aceh Darussalam. The funds in the budget for this program amounted to Rp. 4,24 Billion. These funds derived from MDF, which consists of several bilateral donors such as CIDA, AUSAid, the Netherlands, and DFID.

MDF work together and collaborate with some of the party institutions in the completing the program of the KDP, or Sub-District
Development Program and District. Cooperation referred to cooperation with institutions ILO, INSPIRIT, and CIDA in implementing the training techniques facilitation the facilitator of the subdistrict of Pidie district and Aceh Jaya. Collaboration PPK \& other NGOS doing rehabilitation in the District of Aceh besar. Rehabilitation question is with CARE that undertake the construction of sanitary in the district. Peukan Bada. AUSAid with the redevelopment of the Meunasah \& the Village Office at 108 villages in 8 sub categories of disaster.

MERCY CORPS do the development of Clean Water infrastructure. On the territory of North Aceh in cooperation with Help in the construction of the drainage. And that last is the collaboration of the KDP \& NGO implemented in District Bireun. Cooperation with Child Fund \& Water Mission International to carry out the installation help treatment of drinking water in the District Kutablang and July. In collaboration with the institution of UMCOR carry out the construction of drainage in the District Other Tourist Areas \& Kuala. And in collaboration with GVC Italia, which implement a program of Income Generating program the empowerment of the population which was conducted in District Bireun (MDF, 2011).

\section{Handling Trauma Victims}

Tsunami Aceh gives the impact of one of them is the impact on mental. Mental impact is sustainable. After the occurrence of disasters, symptoms-the symptoms of a reaction to postTraumatic stress or Post-Traumatic Stress Reactivity (PTSR) as feeling numbness or back the events of the Tsunami. Such a feeling often experienced by people who live in the region of most severe damage, i.e. Aceh besar, Banda Aceh and Aceh Jaya. The symptoms of PTSR high also reported by who have experienced traumatic events. Not only experience vicariously that could trigger the symptoms of PTSR, within in communities that suffered severe damage also causes the high PTSR. Recovery is made to handle 


\section{Jurnal Ilmu Pemerintahan: Kajian Ilmu Pemerintahan dan Politik Daerah, Vol. 6 (1), April 2021 - 7}

Agung Danugroho

PSTR is the intervention program of mental health that way get closer to the victim one by one and handle any problems mental the victims (Frankenberg, Gillespie, Preston, 2008). But it is not efficient because the number of victims PSTR a lot of not allow to do this program continuous.

Program intervention mental health, only $7-10 \%$ of victims that get intervention of that kind. Other factors that can also accelerate the recovery is education. Although the level of education is not associated with the risk of experiencing PTSR shortly after the occurrence of The Tsunami, however individuals who have a higher education reported reduced intensity of the symptoms of PTSR faster than time to time (Frankenberg, 2012). It evidenced by a reduced victim of PSTR in the region of Banda Aceh in the year 2007. In addition to the victims PSTR, many of the children who loss of parents during the occurrence of the disaster (Cas, Frankenberg, Suriastini, 2014).

Recovery psychological conducted by the Agency for the Rehabilitation and Reconstruction work partner with Institutions restorer such Foundation Recover (YP). From Foundation Recovered that plunge into the field is a team headed by Jackie Viemilawati. The team of Jackie Viemilawati in the finish the problem of psychiatric disorders after the disaster are with the recovery the trauma of the victims by means of Trauma Healing. How Trauma recovery Healing that with the help of specialized psychosocial support for the disaster victims, such as play activities with the children and drawing, provide motivation and counseling routine (JICA \& Yayasan Pulih, 2006).

Jackie Viemilawati and activists of the Pulih Foundation, settled in Aceh for three year to provide assistance in the form of psychosocial support for the victims. Jackie and the Foundation Recovered using the ways of working approach pyramid by collecting all the victims who have experienced Post-Traumatic Stress Disorder. The next will be held intervention and divided per phase. Intervention what is meant is intervention mental victims. After the intervention made by the victim will go into two phases. The first phase is the distribution of food and tool health, and the second phase is a tent shelter.

In addition approach and Trauma Healing, Endang Moerdopo Head of Development and Evaluation Center Learning Agency for Rehabilitation and Reconstruction (BRR) of Aceh after the tsunami. During the 2 (two) year term as a social worker doing therapy trauma to the victim children of the tsunami on the territory of Lhok Nga. Endang Moerdopo do mentoring by providing dance therapy in children victims disaster. Dance therapy recreative that can help someone to express the emotions themselves. Through the therapy of dance is rehabilitative is the child refugees reaches a balance body and soul, so that it can fix outlook on life and function mentally. Dance therapy conducted by Endang Moerdopo have success is the reduced stress disorders got post-traumatic children of school age in the region of Aceh besar, especially in SubDistrict Lhok Nga intensive Dance Therapy implemented in the region.

\section{Reconstruction Efforts}

Reconstruction is rebuilding all infrastructure and facilities as well as the institution in Aceh. The main target of growth activities economic, social and cultural rights, the establishment of law and order. Efforts reconstruction aims to rebuild the towns, villages and agglomeration district by involving all the affected people disaster, experts, representatives of non-governmental organizations, and the world of business. Target the end of the stage reconstruction is the establishment of life back to the community better in the region affected by the disaster. The stage of reconstruction the coastal region of Aceh can be grouped into two aspects, namely reconstruction in the form of physical and reconstruction in the form of nonphysical. 


\section{Jurnal Ilmu Pemerintahan: Kajian Ilmu Pemerintahan dan Politik Daerah,}

Vol. 6 (1), April 2021 - 8

Agus Danugroho

\section{Reconstruction of Physical}

Plan the redevelopment of the coastal areas of Aceh post-disaster natural tsunami set in the Presidential decree No. 30 of 2005. The regulation contains Master plan for Rehabilitation and Reconstruction of Territory and Life the Community of Nanggroe Aceh Darussalam. Implementation is handled by the The agency for Rehabilitation and Reconstruction (BRR) Nanggroe Aceh Darussalam and is chaired by Kuntoro Mangkusubroto. The scope of the reconstruction among them are the physical aspects, legal aspects, as well as returns right civil and public dignity.

Revamping in the physical aspect in the form of improved return of public facilities, home-home help, schools, and offices government. Public facilities related to the sector of transportation such as roads, bridges, ports, and airports. Improvement on the aspect of law, namely the administration of government, civil rights, guardianship, land, and banking. Improvements in the reconstruction of those listed on the master plan rehabilitation and reconstruction of Nanggroe Aceh Darussalam.

Plan master of rehabilitation and reconstruction in Nanggroe Aceh Darussalam has been established as a general policy. Public policy this is used to perform the reconstruction in the region The Province of Nanggroe Aceh Darussalam. The policy is directed to rebuild communities, rebuild the economy, rebuild the infrastructure, and rebuild the government. In particular, the policy for the year 2007 has been targeted to completion of construction of housing as many as 41,000 housing units so all refugees can be moved from the tent and dwelling while to the house livable. In addition, the completion of the the construction of physical infrastructure, such as roads, bridges, ports the sea and the air, which can support the process of reconstruction and distribution logistics continued as an example of the construction of roads from the District of Aceh Jaya to Aceh Barat District. Segment strategic road that makes for the uplink communications in the along the west coast. At the end of this stage in the year 2007 the emergency response related to the construction of infrastructure has been completed and will then be submitted to the of the Provincial government of Nanggroe Aceh Darussalam to forwarded to build the region of Aceh (Danugroho et al., 2020).

Development physical infrastructure as well as road transport infrastructure and housing BRR is assisted by some donor agencies abroad one of them is MDF. The budget given MDF for the allocation of the construction of the infrastructure of the Aceh region of 245 million US dollars. Of the funds that enter the results of the reconstruction obtained is 20,000 housing units, 100 units of school, 110 office buildings of the village, and 775 units Bridge. In addition to the results of the reconstruction, the MDF also do an attempt of reconstruction of the port. The port is an important part in order to perform the delivery of goods and the logistics required to the process of reconstruction.

Program is called TRPRP or Program of Reconstruction of the Port designed in accordance with the strategy the redevelopment of the port overall supported by the Agency for the Rehabilitation and Reconstruction of AcehNias (BRR). Port built is port of Calang and Sinabang. The port built because located in the disaster area that has the worst impact even the condition of the second port cannot function due to the dock the second port is destroyed. This port is in reconstruction because of its strategic place in order to feed logistical assistance to the region west and south Aceh. Funds used for the completion of the port's reach of 3.78 million US dollar. Simultaneously with the MDF to build the Agency for the Rehabilitation and Reconstruction also do some priority work, among others the completion of the housing program, continue the development infrastructure, the construction aspects of a sustainable economy, and the formation of the joint secretariat. 


\section{Jurnal Ilmu Pemerintahan: Kajian Ilmu Pemerintahan dan Politik Daerah, Vol. 6 (1), April 2021 - 9 \\ Agung Danugroho}

Target next is reconstruction on the aspects of economic development sustainable. This Program aims to reduce poverty and rebuild the Aceh region. Its implementation by way of advance and utilize commodities in the affected region the tsunami, such as Aceh Barat. Commodity of plantation at the level of farmers such as rubber, cocoa and coconut is low the increase. Factory-built rubber (crumb rubber) in the region West Aceh is expected to increase the price of rubber in the level of farmers. ICRAF through the Program Nursery of Excellence along with Local NGOS build a nursery in the community. Training for farmers both men and women and is carried out starting from the plant up to harvest. At the end of the program, 56 rubber factory has been built and 5.542 people have been trained in the region of West Aceh (ICRAF, 2012).

Last is the program the strengthening of regionalization and the establishment of the secretariat of the together. This Program aims to improve the cooperation between donors and the BRR. In addition, this program also makes it easy the distribution of relief and monitor its implementation from one area to other areas. The regional office of who first built only on 8 the territory of the Province of Nanggroe Aceh Darussalam, namely in the region of Banda Aceh, Calang, Meulabuoh, Kutacana, Langsa, Lhokseumawe, Singkil, Sinabang. The regional offices are directly under the leadership of the Agency Rehabilitation and Reconstruction.

\section{Reconstruction of Non-Physical}

Reconstruction non-physical what is meant is actions to correct or restore public service activities and social activities, economic as well as the life of the community. The scope of reconstruction activities non-physical among them are (1) the activities of recovery service associated with education as well as social and cultural life the community, (2) the participation and role of the institution or organization community, the business world, and society, (3) recovery activities the economic activity of the community, and (4) the functions of the public service and the main service in the community. In the implementation done under the coordination of BNPB with working with agencies related to the field that will be in the reconstruction. Reconstruction of non-physical first is on the field education. In the field education component of the reconstruction including is the provision of personnel, curriculum development especially related to disaster and risk reduction efforts disaster, as well as teaching and learning activities.

Tsunami Aceh in 2004 not only destroyed school buildings but also killed tens of thousands of students and teachers in Aceh. Around there are 2000 school building damaged and 2500 educators died the world. Institutions that help to reconstruct the education sector in Aceh's BRR, with the assistance of the agency of the united nations namely UN Agencies (BRR, 2005). Both complete 335 school new and more than 1,100 new teachers or temporary gets training, and 1.7 million textbooks have been distributed the entire region of Aceh affected by the tsunami (Danugroho et al., 2020).

In the field of the economy components that are built are trading the market traditional. The construction of traditional markets in coastal region of Aceh be implemented in order to restore the people's livelihood of the region Aceh. Through the program of the KDP (Sub-District Development Program) built market the village as much as 26 units scattered in several regions such as Banda Aceh, Aceh Jaya, Aceh Besar, and Pidie. The construction of the market rate of this village spend the budget funds as much as Rp. 6.5 Trillion coming from the Ministry of Trade with the assistance of the World Bank (MDF, 2011).

The government to solve this problem is assisted by the united nations agencies namely UNDP. UNDP is the united nations agency that holds a mandate to do efforts to repair the economy of the community, better carry out coordination to the NGO that there is a program the eyes of the search or through NGO. UNDP 


\section{Jurnal Ilmu Pemerintahan: Kajian Ilmu Pemerintahan dan Politik Daerah, Vol. 6 (1), April 2021 - 10}

Agus Danugroho

carry out the Livelihood program in an effort to restore the economy in the region of Aceh. Activities Livelihood done with the cleaning Market Business Development and provide relief tents to the traders. UNDP assisted with the Spanish Red Cross do the provision of seedlings and training in the field agriculture, agricultural processing, and small Industry. In addition, other efforts in restoring the economy of Aceh is to provide venture capital to cooperatives in the Aceh region to the capital as early as on the region of West Aceh. In the region West Aceh community has been able to sell their agricultural with the initial capital of the cooperative loan (Dadek, 2017).

The field Health services, a component of the reconstruction of non-physical among others the provision of medical and non-medical, provision of supply of drugs and medical equipment. In the provision of medical and nonmedical BRR ask for help to the Ministry of Health and WHO. Next The Ministry of Health with the World Health Organization (WHO) to coordinate the volunteer health better than nonGovernmental organizations (NGOS) in and abroad as well as from various provinces in Indonesia to help health services in the province of NAD. For the provision of supply of drugs and medical equipment ministry of Health and the WHO send help the form of all kinds of drugs in every package that contains 120 items of drugs according to WHO standards.

The purpose of from reconstruction to the non-physical it is all health services function back smoothly as before. Success can be judging from several indicators, among others, the death rate is lower than 1 per 10,000 per day and not the occurrence of the outbreak or extraordinary events (KLB) a variety of diseases such as malaria, fever dengue (DHF), Measles, Cholera and Tract Infections Upper respiratory infection (ARI) after the occurrence of the tsunami. Whereas for the impact of natural disasters tsunami, according to international parameters, the numbers his death can be tolerated more than 1 per 10,000 people per day.
The ministry of health in empowering the Department of Health to revitalize in Banda Aceh, Aceh besar, Pidie and Aceh Jaya affected the most severe. While to the East of Sigli until East Aceh, health services relatively can be handled the Department of the health District and local hospital with the help of Ministry of Health east Java, central Java, north Sumatra, Jambi and Riau (Danugroho et al., 2020)

The ministry of health strengthening mentoring and provide assistance facilities so that the organization can function properly, the staff can get and can carry out the work properly. In addition to assisting, strengthening and help facilities the department of Health, Deputy Ministry of health in Banda Aceh and the Head of the The Provincial health office of NAD also coordinate 65 of the health care team international and 96 of the health care team National (Kementerian Kesehatan RI, 2005).

The ministry of health has guidelines in the form of Policy and Strategy Prevention of Health Problems Due to Disaster and Tsunami in The Province of Nanggroe Aceh Darussalam. The policy in question entered in the Rapid Assessment conducted by Ministry of Health. It these include damage assessment, lost assessment and need assessment. The performance of the policy and the strategy are as the following first identifies how the basic needs of both infrastructure and increase in the field of health services. From the process of the Ministry of Health of the overall need $\mathrm{Rp} 2,618$ trillion to the phase of the revitalization and reconstruction. The funds used to finance activities the reconstruction of the hospital services and services of health.

\section{Conclusion}

Based on the above discussion it can be concluded that the Administration of Susilo Bambang Yudhoyono set some policies in dealing with problems that arise due to the events of the 2004 Tsunami in Aceh. In formulating the policy of the Government of Susilo Bambang Yudhoyono, or SBY take a decision to resolve any

Licensed under $(\mathrm{cc})$ BY-NC a Creative Commons Attribution-NonCommercial 4.o International License, 


\section{Jurnal Ilmu Pemerintahan: Kajian Ilmu Pemerintahan dan Politik Daerah, Vol. 6 (1), April 2021 - 11}

\section{Agung Danugroho}

problems gradually. The first step SBY at that time is to set the status of the 2004 Aceh Tsunami disaster became a national disaster. Background determination of the status of natural disasters Tsunami Aceh 2004 to the national disaster includes several criteria, among others, (1) Casualties and Losses incurred after the occurrence of a natural disaster Tsunami Aceh 2004, (2) the Conditions of Service of the Public after the occurrence of the Tsunami in Aceh in 2004, and (3) the Conditions of Aceh BUDGET. With so Indonesia, especially Aceh region affected are open to receiving help from donors abroad. The next step, the Government of SBY establish the several phases of disaster management, among others, the stage of the Phases of Emergency Response, rehabilitation efforts and the efforts of reconstruction. The first stage, the Phase of the Emergency Response conducted 3 months after the occurrence of the events of the tsunami, which is January to March 2005. The stage of Rehabilitation carried out in April 2005 to December 2006. The stage of the Reconstruction carried out after the response phase is implemented and coincides implementation of rehabilitation which began in July 2005 to December 2009. Of the third phase Government of SBY along with donor agencies to build the region affected by the tsunami of the infrastructure of roads, ports, offices public services as well as restoration of public services along with the trauma of the tsunami victims.

The handling of the Tsunami in Aceh which is made by the President are also generating mechanism and readiness is in dealing with natural disasters that will occur in the future. In the early period after the Tsunami occurred, the situation becomes a major challenge for institutions and governance. The right step taken by the Government of Indonesia is to immediately establish the Agency for the Rehabilitation and Reconstruction with a strong mandate to set priorities and coordination. This action not only make sure the funds in accordance with the needs, but also in line with global practices to ensure accountability and transparency. In the process of reconstruction of the Government of SBY also strive to put the community as a process of reconstruction of a natural disaster. Reconstruction on the 2004 Tsunami in Aceh involve the community through a process of participatory risk mapping, planning local investment, as well as the reconstruction of the house that is specified by the owner. The process of empowerment as it make the people bounce back, and in the long term become more powerful and secure. By putting people at the center of the planning and implementation of the reconstruction process, people can feel satisfied, have a sense of having strong and with results even better.

\section{References}

Australian Government Department of Foreign Affairs and Trade. (2014). Indian Ocean Tsunami.

BRR. (2005). Six-Month Activity Report of the Implementing Agency for the Rehabilitation and Reconstruction of Nanggroe Aceh Darussalam and Nias.

Cas, Frankenberg, Suriastini, \& T. (2014). The Impact of Parental Death on Child WellBeing. Demography.[Crossref]

Dadek, T. (2017). The Tsunami of Love; Records of Events Suspected Doomsday. PeNa Foundation.

Danugroho, A., Umamah, N., Marjono, Sumardi, \& Pratama, A. R. (2020). Aceh tsunami and government policy in handling it: a historical study a historical study. IOP Conference Series: Earth and Environmental Science, 485. [Crossref]

Dunn, W. (2003). Public Policy Analysis. Gadjah Mada University Press.

Frankenberg, Gillespie, Preston, \& T. (2008). Mortality, The Family and The Indian Ocean Tsunami. The Economic Journal.

Frankenberg. (2012). In The Wake of The Tunami: Destruction of Comunity Revisited. Journal of Health and Social Behavior, 498514.

Gottschalk, L. (1985). Terjemahan oleh Nugroho Notosusanto. Mengerti Sejarah. UI Press. 


\section{Jurnal Ilmu Pemerintahan: Kajian Ilmu Pemerintahan dan Politik Daerah,}

Vol. 6 (1), April 2021 - 12

Agus Danugroho

ICRAF. (2012). Rebuilding Aceh: Learning from the Results of Research and the PostTsunami Aceh Rehabilitation Program.

JICA, \& Pulih, Y. (2006). Together Reaching For Asa. Center for Psychological Crisis, University of Indonesia.Bersama Meraih Asa. Pusat Krisis Psikologi Universitas Indonesia.

Kementerian Kesehatan RI. (2005). Indonesia Berhasil Tangani Masalah Kesehatan Akibat Bencana Di Prov. NAD dan Sumut.

MDF. (2011). Kemitraan Untuk Mencapai Keberlanjutan.

Sisira \& McCawley. (2010). The Asian Tsunami: Aid and Reconstruction After a Disaster. Edward Elgar Publishing Limited.

Sri Cahyadi Nugroho. (2017). The Easerum Epicentre Pusat Studi Gempa Bumi Di Kabupaten Bantul. Universitas Atma Jaya.
Swiss Agency for Development and Cooperation. (2009). Switzerland's Commitment in Indonesia Following the Tsunami.

U.S. Agency for International Development. (2005). Bureau for Legislative and Public Affairs: Tsunami Relief.

van Eck, N. J., \& Waltman, L. (2010). Software survey: VOSviewer, a computer program for bibliometric mapping. Scientometrics, 84(2), 523-538. [Crossref]

\section{Author Profile}

Agus Danugroho is a Masters student Universitas Gadjah Mada. He actively writing scientific articles related to the history of natural disasters, central and regional government politics, culture, and family resilience. 